International Journal of English Literature and Social Sciences
Vol-6, Issue-2; Mar-Apr, 2021
Journal Home Page Available: https://ijels.com/
Journal DOI: $10.22161 /$ ijels

\title{
Divided and Bound by Nationalism: A Postcolonial Commentary
}

\author{
Saraswathi CK
}

Department of English, Vivekananda College of Arts, Science and Commerce, Puttur, DK Dist., Karnataka, India Research scholar, Department of English, Mangalore University, DK Dist., Karnataka, India

Received: 29 Jan 2021; Received in revised form: 14 Mar 2021; Accepted: 15 Apr 2021; Available online: 28 Apr 2021 (C)2021 The Author(s). Published by Infogain Publication. This is an open access article under the CC BY license (https://creativecommons.org/licenses/by/4.0/).

\begin{abstract}
Scholars and critics alike agree that nationalism has been an important defensive feature of decolonization struggles in the Third World. Critics like Benedict Anderson, Bhikhu Parekh, Partha Chatterjee, Meenakshi Mukherjee, Ernest Gellner and Leela Gandhi have spoken extensively on its relevance to decolonizing efforts in the postcolonial world. Indian writers of fiction in English have deliberately or otherwise talked about 'nation' in their works, in their debates, talks and interviews. It is one of the ways that provides methods of communication of a sense of identity and belonging. For some, it provides, in contrast, methods of communication of some sense of loss and longing. Many authors of fiction and non-fiction in English today have successfully brought out very telling debates of the concept of nation in their works. That is the reason why I chose to write on the concept of nation as propounded by a few important critics. This article will therefore delve into some of the arguments of the eminent critics on the concept.
\end{abstract}

Keywords - colonial experience, identity, imagined community, nation, political.

\section{INTRODUCTION}

Studies on the rise and emergence of nations for innumerable reasons or excuses, with vested interests or otherwise, for convenience and inconvenience, for the self and the 'other' have invariably shrouded the already indefinable concept of 'nation'. While an ordinary individual today may attach the words 'patriotism', 'government', 'belong', 'culture', 'people', 'language', and 'religion' to the word 'nation', it is worthwhile to note that the concept of nation has been arrived at, imagined, debated, assembled, disassembled and reassembled by different kinds of people- philosophers, men of religion, men of letters, colonialists, reformers, scientists, sociologists, social anthropologists, political scientists, businessmen, cartographers, politicians, the rich, the poor, the young, the old, and so on. In ever so many ways, nations, since ages, have been marked, constructed, imagined, defined, represented, legitimized, fought for, broken and forged. The hegemonic manifestations almost always present make the reception and response from the receiving end an enormous corpus to be digested and thought over.

\section{LITERATURE REVIEW}

It is evident that definitions of 'nation' vary, depending on the subject of approach. For a beginner of language, and for a layman, the Oxford dictionary defines it from the political point of view. It could also be said that 'nation' is largely imagined and understood as a geographical entity, encompassing qualitative aspects like culture, religion, history, and belongingness; and quantitative aspects like people, government, resources and security. Ask a schoolgoing child of today about 'nation', his/ her mind goes to a large imagined area stretching much beyond the 'marked' courtyard of his/ her house, inclusive of an anthem, an emblem, a flag, a national animal, border defence forces and festivals. And the word 'my' or 'our' is almost always pronounced, as if nation has always been undisputedly out 'there'. Benedict Anderson, one of the foremost proponents of the study of 'nation' in the recent times, 
defines it as "an imagined political community - and imagined as both inherently limited and sovereign" (Anderson, 1983, p.6). He holds it in "an anthropological spirit" (Anderson, 1983, p.5) he says, and elaborates on the words he has presented in his definition.

\section{EVOLUTION OF NATION AND ITS CONNOTATIONS}

According to Anderson, nation is "imagined because the members of even the smallest nation will never know most of their fellow-members, meet them, or even hear of them, yet in the minds of each lives the image of their communion" (Anderson, 1983, p.6). The imagination itself has undergone profound change, from the case of specific imaginations based on family ties and 'kinship', therefore language, inclusive of dialects and cultural practices, if not totally homogeneous religious practices, to a geographic and political mode of imagination. Anderson writes that it is imagined as 'limited' (Anderson, 1983, p.7) because of the marks of boundaries and borders that limit the geographical and mental construction of nations: imagined as 'sovereign' because the concept was born in an age in which Enlightenment and Revolution were destroying the legitimacy of the divinely ordained, hierarchical dynastic realm (Anderson, 1983, p.7) and imagined as a 'community' (Anderson, 1983, p.7) because of the concept of fraternity. He introduces the word 'piracy' when he speaks of nation; because that is the way he thinks it is forged into existence. Ironically enough, nations, considered unified political entities, are forged, or imagined by their political division into state and its constituents.

Therefore, 'nation' and its derivative words 'national' and 'nationalist' have in a way, in the 1970s, been looked at as "a matter of ethnic politics" (Chatterjee, 1993, p.3) The potential and notoriety of this concept of nationalism, the word itself coming into general use only during the end of the nineteenth century (Anderson, 1983, p.4), have been captured by Chatterjee thus, "like drugs, terrorism and illegal immigration, it is one more product of the Third World that the West dislikes but is powerless to prohibit" (Chatterjee, 1993, p.4). Whether it is by Anderson or Parekh or Chatterjee, the study of 'nation' goes back to its roots in antiquity, memory and forgetting - intentional or otherwise, its acceptance or otherwise nailed to different modes of life, time and space. If Anderson makes it a point to explain the perplexity of theorists of nationalism about the "three paradoxes" (Anderson, 1983, p.5) in defining 'nation' and 'nationalism' before he arrives at his own workable definition, Chatterjee states that nationalism was 'recognized as a 'problem' for it to a subject of general debate and it resulted in the prejudiced view in the 1950s and 1960s: a feature of the victorious anticolonial struggles in Asia and Africa" (Chatterjee, 1993, p.3). The volatile and the near-impossible nature of giving a unified meaning to these words in question is made clear.

\section{RELIGIOUS AND CULTURAL IDENTITY}

Further, Anderson argues that the concept of nation historically was born in the eighteenth century, the Age of Enlightenment, with the decline of the authority of religion and religious thought. Till then religion played an important role in comprehending the "overwhelming burden of human suffering" (Anderson, 1983, p.10) thus transforming fatality into continuity. With the downfall of the unanimous authority of religion for the functions of the state, with the "Disintegration of Paradise" (Anderson, 1983, p.11) and "Absurdity of salvation" (Anderson, 1983, p.11), there arose the inevitability of another idea of an imagined community. Though not a direct result of the downfall of religion, the concept of nation and nationalism owes its birth to the historical, "large cultural systems that preceded it, out of which - as well as against which-it came into being" (Anderson, 1983, p.12). And those cultural systems are "The Religious Community" (Anderson, 1983, p.12) and "The Dynastic Realm" (Anderson, 1983, p.12).

Anderson's study, going back to ancient history, delineates the fact that religion declined due to two factors: one, exploration and colonization of the East and two, gradual ebbing of the sacredness of Latin, the truth language. Language could no longer be unifying forces of class and clan, instead communities gradually got "fragmented, pluralized and territorialized" (Anderson, 1983, p.19). Also, Anderson points out, the invention and gradual massive production and circulation of the novel and the newspaper, that he famously calls 'printcapitalism' (Anderson, 1983, p.36) contributed to the formation of the imagined communities, for good or bad. This print-capitalism, in turn owed its success directly to the impact of Reformation.

Even there, Anderson and Chatterjee have points of departure, wherein we see that Chatterjee objects to Anderson's argument of nationalisms other than in the Western world (largely anticolonial nationalisms) deriving from certain "modular" forms already made available to them by Europe and the Americas" (Chatterjee, 1993, p.5) because for him, results of nationalist imagination in the colonized 'nations' are "posited not on an identity but rather on a difference with the "modular" forms of the national society propagated by the modern West" (Chatterjee, 1993, p.5). He writes that nationalism and the 
concept of nation takes a very narrow, almost false view if looked at only as a political movement. He defines the process thus - "Anticolonial nationalism creates its own domain of sovereignty within colonial society well before it begins its political battle with the imperial power. It does this by dividing the world of social institutions and practices into two domains- the material and the spiritual" (Chatterjee, 1993, p.6). The colonial hegemonic power gets no access to the spiritual domain, which bears the "essential marks of cultural identity" (Chatterjee, 1993, p.6). Chatterjee thus argues that the concept of nationalism is born not as an imposed identity given by the colonizer, instead as an innate generated process for a difference with the colonizer. However, Anderson and Chatterjee agree on the point that 'language', 'print-capitalism' and 'family' are the areas within the spiritual authority that nationalism "transforms in the course of its journey" (Chatterjee, 1993, p.6). Anderson writes, about the majestic change brought about by print-languages, "they created unified fields of exchange and communication below Latin and above the spoken vernaculars" (Anderson, 1983, p.44). And, the "fellow-readers, to whom they were connected through print, formed, in their secular, particular, visible invisibility, the embryo of the nationally imagined community" (Anderson, 1983, p.44).

When it comes to nationalist response to colonial experience, Anderson focuses mainly on the Indonesian states, while Parekh and Chatterjee write more on the native Indian nation construct. Chatterjee notes, "The colonial state, we must remember, was not just the agency that brought the modular forms of the modern state to the colonies; it was also an agency that was destined never to fulfil the normalizing mission of the modern state because the premise of its power was a rule of colonial difference, namely the preservation of the alienness of the ruling group" (Chatterjee, 1993, p.10). It is worth mentioning here a very valid argument that, "The fact that Britain had conquered India did not signify the moral superiority of its civilization" (Raychaudhari, 1989, p.70).

Particularly hitting upon the Hindu responses to British imperialism, Parekh writes, "Rather than concentrate on colonial rule and ask whether to welcome, or fight against it, as the Muslims were to do later, Hindu leaders, almost to a man, located and discussed it with the wider context of their social regeneration" (Parekh, 1999, p.40). He notes that among the four arguments that Indians, particularly Hindus, including relying on scriptures, one was to legitimize adoption of European values and practices. Meanwhile, Anderson has aptly noted the bitter responses of multitudes of Indians to the colonial rule, as represented by Bipin Chandra $\mathrm{Pal}$ in his memoir, that Indian magistrates sadly, injudiciously, deliberately alienated themselves from the material and spiritual domain of native India. The aftermaths of Anglicization in producing "thousands of Pals" (Anderson, 1983, p.93) is horrifying. Anderson notes that "Nothing more sharply underscores the fundamental contradiction of English official nationalism, i.e. the inner compatibility of empire and nation" (Anderson, 1983, p.93). Seen from the other perspective too, in terms of enabling themselves, colonialism has had its role to play, as Parekh notes, "The fact that Hindu social self-consciousness was precipitated by and developed simultaneously with the consciousness of colonial rule, each shaping and in turn being shaped by the other, meant that Hindus could not define and make sense of themselves without defining and making sense of the colonial rule and vice versa" (Parekh, 1999, p.41). Gandhi's struggles for reforming tradition presupposed the belief that "A free, equal and open-minded dialogue between traditions involving an exchange of insights was a necessary condition of their progress. It enabled each to look at itself from the standpoint of others and to gain critical self-understanding" (Parekh, 1999, p.25). Living at a time of infinite challenges for reforming the society owing to the colonial rule, Gandhi constructed and deconstructed, later reconstructed required principles of Hinduism and Christianity: "He took over the Hindu concept of ahimsa, in his view one of the greatest values derived from the profound doctrine of the unity of life. He found it negative and passive and reinterpreted it in the light of the Christian concept of caritas. He thought the latter was too emotive and led to worldly attachments, and so redefined it in the light of the Hindu concept of anasakti. His double conversion, his Christianisation of a Hindu category after suitably Hinduising its Christian components, yielded the novel concept of an active and positive but detached and non-emotive love" (Parekh, 1999, p.26). Parekh delineates three phases of nationalist response to colonial experience. He starts off by saying that some Hindu leaders "saw little wrong in the society, and either showed no interest in British rule or discussed it as inconsequential" (Parekh, 1999, p.26). These were the Traditionalists, "who did not think much of their ruler's 'materialistic, 'irreligious', 'individualist', 'selfish', 'violent', and 'greed-based' civilization” (Parekh, 1999, p.43). The second phase was the Utilitarian response, and the third, evidently denigrated approach - the Critical traditionalism response.

\section{CONCLUSION}

We now understand nationalism and national consciousness can be viewed as partly the result of the colonial encounter and the colonial experience. It can be argued that nationalism sprung up as a force for 
legitimizing one's identity as an individual. It is a very tedious process to undergo for the colonized as well as for the colonizer. Several critics, philosophers, historians, social anthropologists have done substantial amount of research to come to this conclusion. A wide variety of people, be it men of religion, freedom fighters, agriculturalists, students, so on comprised the corpus of the divided responses in unifying the nation, the process of which is still under scrutiny.

\section{REFERENCES:}

[1] Anderson, B. (1983). Imagined Communities. London: Verso Books.

[2] Chatterjee, P. (1993). The Nation and its Fragments: Colonial and Postcolonial Histories. Oxford: Oxford University Press.

[3] Parekh, B. (1999). Colonialism, Tradition and Reform: An Analysis of Gandhi's Political Discourse. New Delhi: Sage Publications.

[4] Raychaudhuri, T. (1989). Europe Reconsidered: Perceptions of the West in Nineteenth Century Bengal. Delhi: Oxford University Press. 